Boise State University

ScholarWorks

World Languages Faculty Publications and

Presentations

Department of World Languages

$10-1-2017$

\title{
Intertexts of the Ecological: Literary Space Revisited in Yanick Lahens's Bain de Lune
}

Jason Herbeck

Boise State University 


\title{
INTERTEXTS OF THE EGOlOGIGAL: \\ Literary Space Revisited in Yanick Lahens's Bain DE LUNE
}

\author{
Jason Herbeck \\ Boise State University
}

The opening lines of Yanick Lahens's Bain de lune (2014) find an unidentified narrator lying on a beach not far from the coastal community of Anse Bleue, staring at the worn, muddy boots of the man who has just discovered her lifeless body. As her narrative reveals, a hurricane has devastated the region over the past three days, and, in the wake of the storm, the deceased protagonist tries to piece together the fragmented memories of her life as a means of determining how she has ended up dead on the sand. From the very beginning of Lahens's novel, however, the protagonist's search for answers - a search to "remonter toute la chaîne de mon existence pour comprendre une fois pour toutes" - is inseparable from the history, evolution, and, indeed, future of the natural environment around her: "Quel ouragan! Quel tumulte! Dans toute cette histoire, il faudra tenir compte du vent, du sel, de l'eau, et pas seulement des hommes et des femmes. Le sable a été tourné et retourné dans le plus grand désordre. On dirait une terre attendant d'être ensemencée."1

Given the prominent role attributed to nature in the opening pages of Bain de lune and the narrative's consistent - one might even say insistentattention to and evocation of the Haitian environment, it is perhaps unsurprising that the back cover of Bain de lune unabashedly hails the novel as "le grand roman de la terre haïtienne.". And while this exceptionally high praise can of course be attributed to the commercial objectives of the publisher (Sabine Wespieser), identifying Lahens's novel as the great novel of the Haitian land(scape) might nonetheless raise eyebrows. After all, this very distinction has long been reserved - unofficially, at least - for Jacques Roumain's 1944 Gouverneurs de la rosée. In this vein, Jack Corzani begins his preface to a 1977 reprint of the novel by suggesting, "La voix qu'ici l'on entendra n'est pas celle d'un romancier défunt . . . mais d'Haïti." As he explains, in reference to the novel's protagonists, "Roumain a écrit son roman comme Manuel a fait l'amour avec Anna[ise], elle-même fondue, mêlée à la terre haïtienne dont elle n'était que l'expression, l'émanation." ${ }^{3}$ 
In fact, in a 2014 Le Point article announcing that Bain de lune had won the prestigious Prix Femina, the status of Roumain's novel is no less prominent; extoling Lahens's novel as "un grand roman . . poétique," journalist Valérie Marin La Meslé characterizes it as inscribed in "la tradition haïtienne du roman paysan, marquée par le classique de Jacques Roumain Gouverneurs de la rosée et plus récemment par La Belle Amour humaine [de] Lyonel Trouillot."

The purpose of this article is not to attempt to ascertain whether Gouverneurs de la rosée or Bain de lune (or any other novel, for that matter) might rightfully be deemed le grand roman de la terre haïtienne. Rather, in calling attention to the abundant intertextuality linking these two novels, the respective publication dates of which are some seventy years apart, I divulge the sustained dialogue of sorts that emerges between the two texts. In placing the works in seemingly direct relation with one another, this latent intertextuality will, however, upon closer examination, ultimately prove responsible for setting them apart on the very grounds of their supposed engagement - that is, the precise physical and social settings to which they each refer. Situated squarely at the intersection of ecocriticism and Haitian literary studies, my analyses juxtapose corresponding scenes and tropes from the two novels as a means to illustrate, by way of these shared fictional spaces, the enduring capacity of literature to grapple with the complicated and ever-evolving relationships between humans and the nonhuman environment.

To this end, I begin by examining allusions to Gouverneurs in two previous works by Lahens, where such intertextuality is more conspicuous. After demonstrating the disillusioned and even critical perspective toward Roumain's iconic novel (and others) that emerges in these earlier works, I turn my attention to the numerous parallels between Gouverneurs and Bain de lune. More specifically, I interpret elements of Bain de lune as hypertextsthat is, textual passages that refer to, or draw from, specific tropes present in a source text, or hypotext: Roumain's Gouverneurs de la Rosée. ${ }^{5}$ Close consideration of this hypertextuality reveals, however, that these common tropes lead to quite divergent trajectories regarding both relationships between humans and the relationship between humans and their natural environment. In the context of what Lawrence Buell has called a "fictive environmentality," my intertextual-ecocritical approach to Bain de lune proposes a close reading of the role and status of the natural environment in Lahens's text. ${ }^{6}$ More significantly, however, in revisiting the ecological underpinnings of the Roumainian hypotext, this analysis reveals how shared natural spaces in literature - what might be understood as intertexts of the ecological - are at times challenged and significantly transformed from 
one text to another as a response to evolving social, economic, political, and environmental realities. Despite claims - including by Lahens herself - that the story recounted in Bain de lune is first and foremost universal, I contend that in being firmly grounded in Haiti by way of both its setting and its latent intertextuality, the novel offers a critical and geospatially specific assessment of the country and its hard-pressed "ecological citizenship" today. ${ }^{7}$

\section{LAHENS AND GOUVERNEURS DE LA ROSÉE: (From) Pretexts to a Hypertext}

Given that the hypertextual relationship between Gouverneurs de la rosée and Bain de lune remains by and large latent, it is interesting to note how - and to what end - Roumain's novel is evoked in more direct fashion in previous novels by Lahens. In both La Couleur de l'aube (2008) and Guillaume et Nathalie (2013), mention of Gouverneurs occurs at the level of the mimesis - that is to say, within the story itself, as a novel that is familiar to the protagonists and that both come to perceive critically, as too far removed from their own lives. A brief consideration of these earlier, more explicit instances of Roumainian hypertextuality in Lahens's writings therefore not only serves in part to substantiate the hypertextual reading of Bain de lune that follows but furthermore provides a first, critical glance of what I later discuss in the context of literature's (own) perceived unreliability and/or impracticality within Lahens's works.

The first instance of this intertextuality is found in La Couleur de l'aube, in which a young woman named Joyeuse explains her unmoved and moreover confused response to various literary works:

J['étais] curieuse, avide de comprendre jusqu'où iraient ceux qui avaient écrit l'histoire du monde et qui voulaient que dans cette histoire je sois le ver de terre que l'on écrase sous le talon. L'école ne m’ayant pas apporté les éclaircissements que j’attendais de toutes ces questions, j’ai trouvé seule les réponses à cette méfiance. À ces dangers. À ces trahisons. Si bien que je ne me souviens pas d'avoir pleuré à la lecture des souffrances de Cosette. Je n'ai pas non plus éprouvé de compassion pour Cendrillon et plus tard, les mésaventures d'eau de Manuel et d'Anaïs m'ont avant tout laissée dans la plus grande perplexité. ${ }^{8}$

Lahens's second reference to Gouverneurs is in her 2013 novel Guillaume et Nathalie, which she had only just begun when the 2010 earthquake hit Haiti, and the (re)construction of which she relates in her 2010 text Failles. In the 
passage in question, the evolving perceptions of the eponymous Guillaume, who works for an NGO attempting to build a multipurpose complex in the region of Léogâne outside Port-au-Prince, are described as follows:

Longtemps Guillaume avait cru à des abstractions. À un paysan bon, à un enseignant exemplaire, à un prolétariat parfait. Parce que Roumain. Parce qu'Alexis. Parce que Marx. Parce que, dans leur jeunesse, des hommes et des femmes comme Guillaume avaient revé d'un monde où les travailleurs de tous les pays pourraient forger le matin et jouer du violon l'aprèsmidi. ${ }^{9}$

In both La Couleur de l'aube and Guillaume et Nathalie, characters are disillusioned by the promises and - more precisely-outcomes proposed by literature. Simply put, Lahens presents her protagonists as being in conflict with the ways in which the world they live is portrayed by literary works - including Gouverneurs de la rosée in both cases. If Joyeuse is left utterly confused by Roumain's novel, and Guillaume eventually comes to regard it skeptically, it is, it seems, due to the abstract or decidedly impracticable notions and ideals that they perceive the novel to embody. While Bain de lune does not explicitly cite Gouverneurs de la rosée, the abundance of hypertextual elements linking the two novels demonstrates that Lahens returns yet again to Roumain's text. However, as I illustrate, the intertextuality in question yields significantly more complex and profound implications - in particular when it comes to the critical role and place of literature within (other works of) literature.

Aside from two epigraphs citing works by René Depestre (Un Arcen-ciel pour l'Occident chrétien) and Marguerite Yourcenar (Feux), and the mention of the soap opera All My Children on the final page of the novel, Bain de lune does not contain any overt intertextuality. ${ }^{10}$ Notwithstanding, there are at least three hypotexts to which Bain de lune makes implicit reference. The most tenuous is La Peste by Albert Camus, an author whom Lahens clearly admires and a handful of whose works she either names, cites, or alludes to in Failles, for instance. ${ }^{11}$ Another is Maryse Condé's 1989 Traversée de la Mangrove, which appears to be lying just below the surface of Lahens's novel on many occasions, including of course at its very beginning, which is immediately reminiscent of Mademoiselle Léocadie Timothée's discovery of Francis Sancher's body, "la face enfouie dans la boue grasse, les vêtements souillés." ${ }^{2}$ While consideration of each of these plausible source novels offers compelling readings of Bain de lune insofar as they demonstrate the interest and influence of particular works and 
authors for Lahens, I will focus here on the most prevalent and recurring hypotext in Lahens's novel - Roumain's Gouverneurs de la rosée.

Bain de lune is comprised of two alternating yet arrhythmic and therefore unpredictable homodiegetic narratives: that of the lifeless woman on the beach, who eventually identifies herself as Cétoute Olmène Thérèse Florival, and that belonging to an unidentified individual who speaks in the first-person plural (nous) as a member of the Lafleur family and their descendants - the Clémestal and Dorival families - the majority of whom live in the community of Anse Bleue, to which Cétoute belongs. ${ }^{13}$ As explained in further detail below, it bears noting that Cétoute is biologically linked to each of the two families whose generations-long enmity Bain de lune recounts: Cétoute's father, Dieudonné, is the son of Olmène Dorival and Tertulien Mésidor. What renders Bain de lune's hypertextuality particularly intriguing is that, rather than denoting specific, finite points of correlation with prior source texts in terms of plot, setting, and characters, hypotextual elements from earlier novels often reappear more than once in Lahens's novel. Accordingly, hypertexts in Bain de lune become leitmotifs of a sort, as they are presented and re-presented under similar but varying circumstances, often by way of different characters or combinations thereof, and, just as importantly, over time. After all, although the time of narration in Bain de lune is essentially limited to the space of several hours the time it takes for Cétoute's lifeless body to be found and transported to Anse Bleue), countless analepses recount several generations of the community's collective and environmental history, "from the US Occupation of Haiti in the early twentieth century to the present day." 14

On a purely onomastic level, Gouverneurs de la rosée and Bain de lune exhibit clear syntactic and thematic echoes in their respective titles (morning/ night) and the names of the principal towns in which their plots unfold (Fonds-Rouge/Anse Bleue). ${ }^{15}$ However, insofar as these nominal similarities serve to allude early on to a link between the two novels, they are in fact quite trivial in light of the extensive, overarching correlations that exist between Lahens's novel and the precise chronological and environmental setting found in Gouverneurs de la rosée. In fact, over the course of Bain de lune's dual narrative, characters retrace paths and confront obstacles amid immediate natural surroundings that are all strikingly congruous to those described in Roumain's novel - to such an extent that the two novels might initially appear to share an almost interdependent, inseparable, and potentially fatalistic trajectory. Examining the circumstances surrounding the mysterious death of Bonal, a member of the Lafleur family, illustrates the myriad ways in which this hypertextuality is achieved on thematic, lexical and historical levels. 
Against the admonition of his mother- "La terre, mon fils, c'est ton sang, ta chair, tes os, tu m'entends!"- Bonal decides to sell his family's land to the wealthy Anastase Mésidor. ${ }^{16}$ Importantly, this land constitutes "la plus belle portion des terres des héritiers Lafleur, dans les grandes plaines fertiles encerclées des montagnes qui dominaient Anse Bleue vers le sud"- a region that the narrative agent goes on to describe in nearhuman terms as "des montagnes aux flancs encore verts, très verts, même si quelques fines lignes claires striaient déjà leur épaisse chevelure." the papers are signed, Bonal's thoughts turn to the many members of his family who will surely come forward to demand their share of what is in reality is a "pitance" of a payment given the wealth of the land he has just surrendered.$^{18}$ Indeed, the last time he tried to determine who in his family was entitled to the land, a violent argument broke out that almost ended in bloodshed; and even though lives were spared, "le morcellement des terres n'avait guère cessé pour autant." ${ }^{\prime 19}$ Consequently, as he leaves the notary's office with a wad of bills in his pocket, he becomes slightly dizzy and has what might after the fact be considered a prophetic vision: "Tous ces souvenirs finirent par tisser dans sa tête un écheveau de sentiers sombres ne menant nulle part." ${ }^{\prime 2}$ Indeed, it is precisely after selling off his family's land and returning home through the sous-bois on the way to Anse Bleue that Bonal disappears. When he reappears that very night, it is in a dream to tell his wife, Dieula, what happened - "Sur le chemin, une douleur aiguë au dos. Infligée par la pointe d'un coutelas. Et puis rien"- as well as where to find his body: "au fond d'un ravin, au milieu de ronces et de bayahondes."

In the pages devoted to Bonal's final days, allusions to historical events such as the uprising of the cacos, the assassinations of Charlemagne Péralte and Benoit Batraville, and the American air attacks on the country's villages situate Anastase's purchase of the land and Bonal's murder in $1920 .{ }^{22}$ Furthermore, the narrative of Bain de lune allows us to identify quite precisely the date - three months after the Marines leave Haiti, in 1934 - when Bonal's son, Orvil, concludes the long initiation required to be recognized in his new role as danti, or leader, of the clan. When Orvil assumes his new title, the extent to which he thereafter looks after everything and everyone in the lakou is made clear: "Nous étions les branches d'un même arbre, soudées au même tronc, et nous devions le rester." ${ }^{23}$ However, the departure of his brother, Philogène, for Cuba only weeks after Orvil's coronation ceremony is the first indication of a much more gloomy, pessimistic, and even apocalyptic image of the Lafleur family and their natural environment. Moreover, whereas the dark, forested impasse envisioned by Bonal shortly after selling his family's land serves as a clear harbinger of the human-caused stabbing to which he subsequently 
falls prey on the path home, the similarly ominous, irreversible fate that his son-Orvil-is unable to overcome is articulated in increasingly environmental terms:

Orvil, tout danti fût-il, ne put rien contre les premières blessures ouvertes d'où fusa le sang de la terre. Contre les premières cicatrices qui saillirent des flancs des mornes. Contre les rivières exsangues qui maigrissaient, maigrissaient. Contre la terre et la rocaille qui encombraient les pieds des versants à mesure que nous les défrichions. Contre la montée en puissance des ouragans. Contre la sécheresse chaque fois plus dévastatrice qui leur succédait. Contre ceux qui partaient, se détachant de l'arbre pour une raison qui n'était pas l'ambition, mais qui lui ressemblait beaucoup. Orvil ne put rien contre ces événements qui ne semblaient vouloir tracer, droit, tout droit, que le chemin à sens unique et sans retour de la fatalité. ${ }^{24}$

As evidenced above, the land is often personified in Bain de lune. Although the earth is still verdant in the early 1920s, when Bonal's shortsighted transaction essentially strips it from a family that has owned and worked it for generations, a few white strands have already appeared on its thick head of hair ("épaisse chevelure"). By 1934, the land is portrayed as having open wounds, bleeding, and scar-ridden. Conversely, both the initial optimism with which Orvil's rise to power is perceived by descendants of the Clémestal family, as well as his subsequent failure, further underscore the bond between humans and environment, as evidenced by the natural (i.e., botanical-arboreal) terms with which the Lafleur family is described in each instance. While its branches are first firmly attached to a common trunk, they are subsequently detached and go missing as family members, unable to survive the increasingly harsh conditions of the region, literally desert Anse Bleue in search of greener pastures. This rhetorical chiasm of sorts, in effectively switching the lexicons traditionally attributed to humans and the natural environment, underscores the precariously symbiotic bond between them while at the same time exposing the growing rift resulting from the formers' mistreatment of the latter. Indeed, the narrative of Bain de lune most acutely attributes the deteriorating state of Haiti's environment to the period of the American Occupation (1915-1934), which witnessed accelerated deforestation due to overuse of resources attributable in great part to the growing demand for charcoal. ${ }^{25}$

Gouverneurs de la rosée, published seventy years before Bain de lune, focuses on this very space - the Haitian countryside - and time period. In fact, 
in addressing the state of Haiti's trees in a recent op-ed piece for the New York Times, Laurent Dubois references Roumain by name in conjunction with the degenerating conditions of the Haitian environment:

Haitian writers like Jacques Roumain . . depicted a rural country tilting into poverty in a steadily worsening cycle: Increased population put more pressure on the forests, whose overuse and destruction made the land less productive. Many left for the cities, which expanded exponentially, their populations dependent on charcoal produced by cutting down trees in the countryside. ${ }^{26}$

As Luiz Augusto da Silveira has suggested, the reference by Gouverneurs' protagonist, Manuel Jean-Joseph, to participating in la huelga - the general strike in Cuba - makes it possible to situate the events of Roumain's novel around the time of the 1933 Cuban Revolution. ${ }^{27}$ Furthermore, given that Manuel spent just shy of fifteen years cutting cane in Cuba before returning to his homeland, we can therefore ascertain that he left Haiti in the early twenties. Consequently, the initial discoveries and observations he makes upon his return not only attest to the same lapse of time recounted in Bain de lune (1920-1934) but also, just as importantly, reveal an essentially identical perspective of how the natural environment has been ravaged during this period. After greeting the "paysage retrouvé" with a hearty hello, Manuel utters an expletive - "Carajo"- that communicates his disbelief upon surveying the once fertile land:

Sa face se durcit, plaquée de sueur. Ge qu'il voyait, c'était une étendue torréfiée, d'une sale couleur rouillée, nulle part, la fraîcheur verte qu'il espérait. .. .

Il contempla, surplombant le village, le morne décharné, ravagé de larges coulées blanchâtres, là où l'érosion avais mis ses flancs à nu jusqu'aux roches. Il essayait de se rappeler les chênes élevés et la vie agitée, dans leurs branches, de ramiers friands de baies noires, les acajous baignés d'une obscure lumière, les pois-congo dont les cosses sèches bruissaient au vent, les tertres allongés des jardins de patates: tout ça, le soleil l'avait léché, effacé d'un coup de langue de feu. ${ }^{28}$

Manuel's dismay upon discovering the barren landscape to which he returns is thus one shared also by Orvil's family in Bain de lune, published seventy years later, when the same landscape is similarly described as full of scars, deforested, and stricken with drought. 
Another prominent leitmotif linking Bain de lune and Gouverneurs de la rosée is the return of the "natif-natal," or prodigal son. ${ }^{29}$ Hypertextually, as embodied by Manuel, the return of this individual is representative of regenerative roots on the level of both family and environment. After all, despite evident physical and social obstacles, Manuel succeeds in providing his community and its immediate environment a second life. As those familiar with Roumain's novel know, soon after returning home to his native Haiti, Manuel learns that a dispute over land inheritance during his absence became deadly and that, ever since, the town of Fonds-Rouge has been divided into two camps. The resulting deep-rooted dissension not only presents an obstacle in terms of Manuel's interest in Annaïse, a girl he happens to meet on his way back into town and who belongs to the other clan, but also constitutes a serious threat to the very future of the drought-stricken community; for as long as the two groups refuse to come together to form the collective workforce, or coumbite, the canal capable of carrying water to the village from the spring that Manuel discovers hidden in the hills cannot be built. ${ }^{30}$ For this reason, the relationship between the inhabitants of Fonds-Rouge and their immediate environment is presented as being entirely dependent on the relationship existing between the two clans. ${ }^{31}$ When Manuel is killed by Gervilen, a member of Annaïse's clan who refuses the prospect of reconciliation, Annaïse and Délira, Manuel's mother, do not seek to avenge his murder but rather publicly attribute his death to a fever brought back from Cuba so as not to jeopardize the unification of the community's members. ${ }^{32}$ Consequently, in the final pages of Gouverneurs, the coumbite assembles and is responsible for bringing the first stream of water down through the hills toward Fonds-Rouge as Annaïse acknowledges the equally promising sign of new life stirring in her womb..$^{33}$ The figure of the prodigal son, motivated by both a broad collective love of community as well as a strong, binding interpersonal love, thus comes to embody real possibility for environmental rejuvenation in Roumain's novel.

Orvil's son, Léosthène, follows closely in the hypotextual footsteps of Manuel. After spending fifteen years in Cuba, Léosthène completes the last leg of his journey home by hitching a ride in a truck, only to discover, as he nears Anse Bleue, a landscape devastated by years of deforestation: "Midi avait sonné depuis une demi-heure et la terre flambait sous les feux de juillet. Léosthène regardait tantôt la plaine, tantôt la mer. Elle renvoyait la lumière en longs faisceaux sur une terre-squelette. Il n'en croyait pas ses yeux: toute la campagne semblait avoir souffert d'une longue maladie dévastatrice." ${ }^{\prime 34}$ Akin to the positive changes that Manuel ultimately brings to Fonds-Rouge in Gouverneurs, the botanical-arboreal lexicon characterizing Léosthène's 
arrival in Anse Bleue seems initially to bode well for the future. If the rise to power of his father had proved incapable of reversing the seemingly doomed fate of the Lafleur-Dorival family and their natural surroundings in the 1930s, Léosthène's return to his family's house forty years later, in the early 1970s, appears to the contrary full of renewed promise: "Tous, hommes, femmes et enfants du lakou, entourèrent la case. Le grand arbre des Lafleur déployait ses branches, et Léosthène les touchait toutes." ${ }^{\prime 35}$ Moreover, Léosthène seems initially undaunted by the stories that each family member, in turn, tells him of the harsh conditions to which he has returned: "La terre vidée de son sang, de sa chair, montrant ses zo genoux, la mer avare, l'éradication des porcs, la mort des petits métiers, la maladie du café, celle des palmistes et des citronniers." ${ }^{36}$ In fact, his impression that "l'arbre [des Lafleur] avait encore des pousses généreuses" is thereafter echoed by the narrative agent, who, after listening to Léosthène recount his travels, optimistically states on behalf of the community: "Nous avons regardé Léosthène, pensifs. Fiers aussi. Léosthène avait prospéré ailleurs, à la force de son poignet, sans léser aucun d'entre nous. L'arbre ne saignait pas. Une branche avait grandi plus que les autres. C'est tout. Léosthène revenait, mais à sa place. ${ }^{.37}$ Ultimately, however, in spite of the numerous tropes, themes and lexicons that serve to link the two novels, the hypotextually crafted promise of Gouverneurs de la rosée is time and again rebuked in Bain de lune.

\section{A Tale of Two Diverging Texts}

In fact, the subsequent paths of the novels' prodigal sons, Manuel and Léosthène, could not be more divergent. In Gouverneurs de la rosée, Manuel's grim appraisal of the parched earth and divided community to which he returns leads him to go in search of a spring that will bring water down from the hills to the suffering village of the plain. Devoting all of his free time to looking for the spring, he perceives this quest as his mission and duty - as an imperative for both the environment and community to which he belongs:

Est-ce qu'on peut déserter la terre, est-ce qu'on peut lui tourner le dos, est-ce qu'on peut la divorcer, sans perdre aussi sa raison d'existence et l'usage de ses mains et le goût de vivre? Mais oui, il recommencerait à chercher, il le savait bien... Ces habitants de Fonds-Rouge, ces têtes dures, ces cabezes de roche, il le fallait cette eau pour retrouver l'amitié entre frères et refaire la vie comme elle doit être: un service de bonne volonté entre nègres pareils par la nécessité et la destinée. ${ }^{38}$ 
Whereas the return of Léosthène - for whom "sa chair et cette terre n'en firent qu'un"- to Anse Bleue initially seems auspicious, his stay proves to be short-lived and essentially ineffectual in terms of both assisting the community at large and repairing the ravaged landscape. ${ }^{39}$ As "des milliers d'hommes et de femmes des villages, bourgs et lieux-dits des environs abandonnèrent des jardins accablés, des squelettes d'arbres calcinés et des rivières qui étaient devenues des veines exsangues pour ... gonfler le ventre de la ville," Léosthène, increasingly aware of the political repercussions and pressures at stake due to François Duvalier's rise to power, refuses to associate himself with "l'homme à chapeau noir et lunettes épaisses." However, in electing not to profit from others' hardships (unlike his brother, Fénelon, who works for the head of the local militia), Léosthène does not attempt to revolt against the power structure in place either. Rather, he decides to leave Anse Bleue.

In stark contrast to Manuel, then, who confronted similarly dire environmental and sociopolitical conditions (although perhaps on a smaller scale), Léosthène hands his parents a wad of bills, saying: "Tiens, voilà. Il faut faire autre chose puisque la terre ne donne plus autant, la mer non plus. Alors vous allez construire un four à pain. Le pain, les hommes en mangent tous les jours." ${ }^{\prime 11}$ In a calculated means of assuring his parents' survival, Léosthène thus "tourna le dos . . . aux blessures de la terre, à ses cicatrices profondes," as well as on the greater community to which he has just returned. Indeed, the pluralized narrative agent of Bain de lune soon reveals the broader, considerably more adverse implications of Léosthène's exclusive gift: "Ce four à pain fit de nous les nouveaux fossoyeurs des mornes et des terres alentour." ${ }^{42}$ For readers of Lahens's novel who come to recognize the aforementioned themes, time period, and environmental geographies linking Gouverneurs de la rosée and Bain de lune, the transformative outcome for the better that might well be anticpated with respect to Léosthène's return thereby results, contrarily, in the first of a series of hypertextual shortcomings.

Two additional hypertextual links to Gouverneurs de la rosée further illustrate the ways in which Bain de lune challenges the outcomes - and thus assumptions - of Roumain's iconic novel. Both involve the returns of other prodigal sons, from the Mésidor family, to Anse Bleue: Anastase Mésidor's son, Tertulien, and Tertulien's grandson, Jimmy. In each case of this intergenerationally deployed trope, Bain de lune appears to align itself more closely with Roumain's hypotext by suggesting the potential and even partial realization of the unification of the two feuding families. However, both of these seemingly propitious opportunities for positive change are also ultimately rebuked. 
The first of the three prodigal son figures described at length in Bain de lune is Tertulien Mésidor. Like Manuel, Tertulien has already spent time abroad (in Cuba, no less) when he first sets eyes on Olmène DorivalOrvil's daughter - who, like Annaïse in Gouverneurs de la rosée, has hardly set foot outside of the immediate vicinity of her hometown. As opposed to Manuel, however, Tertulien has not been cutting cane, but rather dancing the son with women in Havana. ${ }^{43}$ It bears noting in this regard that, notwithstanding the many hypertextual elements discussed thus far, socioeconomic factors sharply distinguish Gouverneurs and Bain de lune in terms of their respectively fractured communities. While the community of Fonds-Rouge is divided into two equally poor and wanting halves, the social dynamic in Bain de lune stresses the considerable inequalities separating the two groups: "[Tertulien] faisait partie des autres - vainqueurs, nantis, conquérants-, non des vaincus, des défaits comme [Olmène]. Comme nous. Pauvres comme sel, maléré, infortunés." ${ }^{44}$ Thanks in large part to Bonal's decision to sell his family's land to Tertulien's father (Anastase), Tertulien has come to be revered as a don - a "grand propriétaire terrien" who possesses three-fourths of the land on the other side of the mountains from Anse Bleue. ${ }^{45}$ However, while his wealth is in part inherited, Tertulien boasts openly of the variously illicit means by which he has continued to gain as well as wield his power: "À force de compromissions et de bassesses, j’ai accumulé une petite fortune, des biens, des biens, encore des biens. Je suis plus fortuné que tous les habitants de ces cinq villages réunis. Rien n'a jamais arrêté mon bras quand je voulais tuer, voler, violer. Rien." ${ }^{36}$

When Tertulien first spies Olmène in an open market, his sexual urges perpetuate the family's capitalistic, "land grab" mentality. In fact, on a metaphorical level, the passage recounting Tertulien's thoughts evokes lexically the scene in Gouverneurs where Manuel and Annaïse make love at the spring: "Tertulien Mésidor garda les yeux fixés quelques secondes sur cette bande de tissu qui cachait la source et la fleur d'Olmène Dorival. . . . [Son] désir . . fut immédiat et brutal, et fit monter en lui des envies de jambes emmêlées, de doigts furtifs, de croupe tenue à même les paumes, de senteurs de fougères et d'herbe mouillée. ${ }^{{ }^{\prime}+7}$ Despite the clearly predatory nature of this first encounter between Olmène and Tertulien, the interfamily union that results hints initially in Bain de lune at the broader alliance and harmony of the community realized in Roumain's novel: "Malgré les mondes qui les séparaient, malgré les souvenirs qui avaient plombé les premières minutes de leur rencontre, un étrange marché fut conclu." ${ }^{\prime 48}$ Hence, notwithstanding their obvious age and socioeconomic differences, as well as the lecherous as opposed to loving circumstances that bring them together, Olmène and Tertulien's marriage hints early on, and in 
terms immediately evocative of the eponymous gouverneurs de la rosée, at the promising implications of their union: "Olmène, maîtresse des sources et des lunes . . . venait de retourner l'ordre de l'univers." ${ }^{49}$

When, as with Léosthène, this hypertextually anticipated resolution is frustrated in Lahens's novel, the terms of this rejection, too, are articulated in a lexicon that can be directly linked to the Roumainian hypotext: "Aucun coumbite ne fut organisé pour sarcler ce lopin de terre sur le flanc du morne Lavandou et y poser les pieux d'une maison en dure. . . . Tertulien convoqua plutôt des manœuvres qui arrivèrent de Baudelet." ${ }^{, 50}$ Whereas the land is in fact prepared for future harvests, the ecological outcome of this contracted - as opposed to locally sourced - work effort does not bode well for the greater community of Anse Bleue. Moreover, Olmène eventually decides that she can no longer endure her husband's physical and emotional abuse and runs away from home, thus confirming that their marriage has amounted to failure on both personal and communitarian levels.

A similar hypertextual failure plays out when yet another prodigal son of sorts, Jimmy Mésidor, Tertulien's grandson, meets Cétoute - the woman whose narrative begins the novel. Born abroad because his father, Mérien, fled the wrath of his father, Tertulien, Jimmy "returns" home "pour reprendre ses droits et possessions sur ses terres." "If Tertulien and Olmène's interfamily relationship, predicated on Tertulien's lascivious character, might be considered doomed from the start, the love interest that develops between Jimmy and Cétoute is notably initiated by the latter: "Moi, je le suis à la trace. Petite bête à l'affût dans l'herbe sauvage. Je m'accroche à ses talons. ${ }^{.52}$ However, any hope that their relationship might develop into something enduring and mutually endearing is lost when Jimmy takes Cétoute by the arm, leads her into a room above a bar, and violently has sex with her. As with Tertulien and Olmène's unsuccessful union, the one between Jimmy and Cétoute thus also fails to amount to a meaningful rapport, let alone a broader, more collective appreciation for and sharing of the land and community. In fact, not only is the solidarity associated with the Roumainian coumbite and Fonds-Rouge's communal and ecological revival again denied, but the Lafleur family incurs further suffering as a direct result of the relationship. After all, as is revealed only toward the end of the novel, the interfamily violence has in fact only further escalated, the proof of which is revealed when Cétoute's meandering firstperson narrative eventually leads her to realize that she was killed by none other than Jimmy. Seemingly true to the name bestowed upon her by her mother, who "voulait . . par-dessus tout que je sois la toute dernière," Cétoute thus appears to represent the literal and figurative "dead end" of the Lafleur family's genealogical line..$^{53}$ 
In this respect, one of Cétoute's final utterances in Bain de lune can be read as yet another firm hypertextual rebuke of the harmonious and optimistic ending - and, indeed, future - proposed in Gouverneurs de la rosée. As readers familiar with Roumain's novel are well aware, the parting images of the text depict Annaïse and Manuel's mother, Délira, sitting on a bluff overlooking Fonds-Rouge. Motioning toward a wooded hill, Annaïse points to the men at work on the canal, at which point their singing can be heard: "Manuel Fean-foseph, bo nègre vaillant, enbébo!"'54 Moments later, the singing stops abruptly and the women, rising to their feet, witness the first, thin stream of water running down into the plain where ditches have been prepared to redirect the water to gardens and fields. When Délira asks, mournfully, "Pourquoi es-tu mort, Manuel?," Annaïse quickly responds that he isn't, and the novel closes with these words: "Elle prit la main de la vieille et la pressa doucement contre son ventre où remuait la vie nouvelle." ${ }^{55}$

Quite to the contrary, as the men carrying Cétoute's body across the beach approach Anse Bleue, the lifeless narrator notes:

J'entends une espèce de son incontrôlable, comme quelque chose qui sortirait du ventre d'un animal qu'on égorge. Et qui, après avoir creusé son trou noir dans les os au plus profond de la chair, monte dans la poitrine, serre la gorge et gicle de la bouche à l'air libre. Ma mère crie mon nom très distinctement dans des aigus assourdissants: "Cétouuuuuute, Cétouuuuuute." ${ }^{56}$

In stark contrast to Gouverneurs de la rosée, then, in which the chanting of Manuel's name during the coumbite confirms that his death has not been in vain and that the village of Fonds-Rouge will recover on societal, biological, and ecological levels, Cétoute's name reverberates near the end of Bain de lune as a (hypertextual) death rattle. Not only has Cétoute's mother learned in the wake of a deadly storm that her daughter has died, but readers, knowing that she has died at the hands of Jimmy, might therefore interpret Cétoute's death as a definitive break between Lahens's novel and the Roumainian hypotext whose tropes, themes, and lexicons it so often elicits.

\section{Of Coumbites ANd Coopératives}

Martin Munro has written that "Haitian literature . . . has traditionally functioned as a site in which are debated and explored many of the issues that the state ignores and appears unable to act upon," adding, "Fiction is a valid and dynamic means of creating historical knowledge. ${ }^{\prime 7}$ As 
testament to Munro's assertion, Lahens, speaking about what it means to write during a 2017 roundtable discussion on the topic of "Littératures caribéennes au présent: Histoire(s) en Relation, nouveaux partages éc(h)opoétiques," evoked what she termed her "travail sur le temps," noting, "Dans mon œuvre il y a vraiment une interrogation sur la manière de traiter le temps. ${ }^{\prime 58}$ In this vein, the intertextual implications of Lahens's Bain de lune illustrate how literature's exploration of issues also at times interrogates the positions, assumptions, and even solutions of other, previous works of literature. Furthermore, the resulting intertextuality - or, more precisely, in the case of her 2014 novel, hypertextuality - articulates evolving perspectives, frustrations, and responses to fundamental concerns such as Haiti's environment. Along these lines, and in recognition of how Lahens revisits tropes found in Gouverneurs de la rosée and rewrites them to decidedly different ends in Bain le lune, the latter novel's resultingly divergent narrative need not be interpreted as presenting a necessarily bleaker outlook on societal or ecological conditions in Haiti, nor as reframing potential solutions to such issues in less attainable terms. Rather, the persistent hypertextual rebuke to Gouverneurs presented in Lahens's novel might be better understood as a critical reassessment of obstacles to be negotiated at what Graham Huggan refers to as "the intersections between postcolonial and ecological concerns.."59

In his 2005 article on "greening" postcolonialism, Huggan explains the profound relationship linking humans and their immediate natural environment. On the one hand, "ecological disruption is coextensive with damage to the social fabric"; on the other, "environmental issues cannot be separated from questions of social justice and human rights." ${ }^{\prime 60}$ He goes on to identify several overlapping fields ripe for "critical dialogue" when it comes to postcolonial and ecological-oriented criticism, concluding:

It seems necessary to reaffirm the potential of the environmental imagination to envision alternative worlds, both within and beyond the realm of everyday human experience, which might reinvigorate the continuing global struggle for social and ecological justice. To be sure, the utopian aspirations of postcolonial criticism might well conflict, rather than coincide, with those of ecocriticism, while the early history of the twenty-first century ... might well suggest that there is little room left for utopian thought. ... [It is] urgently necessary ... [to imagine] alternative futures in which our current ways of looking at ourselves and our relation to the world might be creatively transformed. ${ }^{61}$ 
In the context of Huggan's critical charge and the hypertextual challenges leveled in Bain de lune, it is revealing to reconsider the near-utopian state that is realized at the conclusion to Gouverneurs de la rosée. ${ }^{62}$ The virtually idyllic ending of Roumain's novel leaves little room for uncertainty with respect to the all-encompassing promise of Fonds-Rouge's social, biological, and environmental regeneration. The compelling link between social justice and the environment raised by Huggan, however, divulges an often overlooked failing in Gouverneurs' utopian society. After all, it is evident that Manuel's murder is promptly covered up in order that the greater community and environment might survive - and, one might even assume, prosper. In the interest of restoring greenery to the arid plane and reconciling the divided community, Manuel himself insists in his final breaths that the true cause of his death be silenced:

Si tu préviens Hilarion, ce sera encore une fois la même histoire de Sauveur et Dorsica. La haine, la vengeance entre les habitants. L'eau sera perdue. Vous avez offert des sacrifices aux loa, vous avez offert le sang des poules et des cabris pour faire tomber la pluie, ça n'a servi à rien. Parce que ce qui compte, c'est le sacrifice de l'homme. C'est le sang du nègre.... [L]a réconciliation, la réconciliation pour que la vie recommence, pour que le jour se lève sur la rosée. ${ }^{63}$

Whereas Gouverneurs de la rosée thus prioritizes ecological justice over human justice, we might therefore read the frustrated hypertextuality in Bain de lune as challenging the very notion of such a sacrifice - that of the individual but also, just as importantly, that of justice itself. It bears noting in this respect that Bonal's murder is never resolved. However, the failure of his family to identify the assassin and bring him to justice is attributed to a seemingly class-based resignation from which they have absolutely nothing to gain: "Nous avons hurlé notre douleur, puis nous nous sommes tus. Retournant à notre placidité. À notre retenue. À notre silence paysan. ${ }^{.64}$ Quite to the contrary, when Cétoute is murdered against the backdrop of the disillusionment surrounding Aristide's rise to power, the first-person pluralized narrative agent asserts that her death will not go unpunished: "Pour la première fois, des hommes de l'ordre et de la justice fouleraient la terre d'Anse Bleue." ${ }^{\prime 65}$

This determined call for justice near the end of Bain de lune marks an emphatic turning point in Lahens's epic narrative. Hence, while Robert Sapp argues that "Bain de lune sidesteps Haiti's more recent history . . . in favor of representing an era that evokes the indigéniste sentiment of Jacques Roumain's Gouverneurs de la rosée," it is possible to differentiate 
starkly conflicting messages in the two novels. ${ }^{66}$ Both Cétoute's death at the hands of a member of the rival family, and the assurance that justice for her death will be sought, demonstrate the extent to which interpersonal love - the power and resilience of which are unmistakable in the final pages of Gouverneurs - is greatly discredited in Bain de lune as a real or symbolic catalyst for social and environmental change. Moreover, as illustrated above, each of the prodigal sons in Lahens's novel (Léosthène, Tertulien, and Jimmy) diverges from Manuel's hypertextual footsteps; whether on account of their fatalistic assessment of the natural resources around them, a short-lived investment in their community, the decidedly limited scope of this investment in terms of family/community, or simply the hubris driving their desire for economic gain, all fail miserably to embody a source of hope, renewed energy, and collective enterprise for Anse Bleue's immediate and distant future.

Consequently, the firm pledge to bring Cétoute's murderer to justice notwithstanding, readers of Bain de lune might wonder what is left in the wake of the hypertextual deconstruction of Roumain's utopic ending/new beginning. After all, if love fails to provide the impetus necessary for social and environmental renewal/revival, and the amorous "unions" between the Mésidor and Lafleur/Dorival families are therefore unsuccessful in bringing the greater community of Anse Bleue together on equal terms, Lahens's novel, in spite of its numerous ties to Gouverneurs de la rosée, might (merely) amount to the very antithesis of its hypotext. Epitomized by the lifeless Cétoute, the community of Anse Bleue appears destined to an increasingly precarious, doomed existence, with little to no recourse available with which to avert mounting socioeconomic divisions and ecological devastation.

The void created in Lahens's novel by the hypertextual shortcomings of Gouverneurs de la rosée is, however, eventually filled by Cétoute's brother, Abner Florival, who, "quand il fut assez grand ... voulut . . . nous attirer vers un monde qui n'existait pas." ${ }^{\prime 7}$ Wanting to talk only about développement, Abner concerns himself first and foremost with the natural environment and, in so doing, offers pertinent advice that not only concerns the entire population but moreover can be considered applicable to everyone's daily lives, largely irrespective of family or social class: "Si vous coupez les arbres, pas de développement. Si vous plantez dans les terres de café des haricots, la terre va s'en aller et pas de développement. Si vous déféquez dans les rivières, pas de développement." ${ }^{68}$ In the hypertextual shadow of Gouverneurs, Abner's determination and personal investment when it comes to the region of Anse Bleue are of course reminiscent of Manuel's. And yet Abner's actions, while thematically linked to Roumain's novel, propose 
to realize real change in fundamentally different ways, as demonstrated by telling lexical shifts. Hence, parallel to Manuel's search for a spring in the hills (source), conception of a child with Annaïse (grossesse), and plans to organize a collective work force (coumbite) to deliver water to the village below, Abner "creusa un puits, essaya des semences et organisa une coopérative" with the intention to irrigate the land surrounding Anse Bleue. ${ }^{69}$ Juxtaposed with the hypotextual lexicon of Gouverneurs, the terms with which Abner's project is described accentuate vital new solutions to persisting generational problems and, more precisely, speak to the evolving social, political, and even technological approaches at issue.

In this way, the societal reconciliation founded on individual love in Gouverneurs de la rosée, proven to be a failure on at least two hypotextual accounts in Lahens's novel, is recast in a professional, pseudopolitical context in Bain de lune. Whereas Tertulien's union with Olmène results in his decision to forgo a coumbite in favor of contracting the project to workers from a neighboring town, Abner collaborates with none other than "Jean-Paul, un descendant des Mésidor ... qui devait entamer un ambitieux programme d'irrigation des terres et de mise sur pied de la coopération." "70 Seemingly unwilling or unable to forge bonds based on personal relationships, the formerly divided members of the community of Anse Bleue are - at the conclusion of Bain de lune - described planning a cooperative together. Abner's efforts will thus presumably allow relationships among the town's inhabitants, as well as their collective stewardship of the natural environment, to begin to prosper rather than be forsaken.

Given the many instances where tropes, chronologies, and lexicons found in Gouverneurs de la rosée are ultimately denied their hypotextually crafted outcomes in Bain de lune, one might conclude that Lahens's novel follows in the footsteps of her earlier works by rebuking Roumain's iconic novel. Accordingly, Bain de lune not only challenges the means by which the utopic outcome of Gouverneurs is realized but, more generally, underscores the abstractions and ideals of literature that so clearly frustrate the protagonists of La Couleur de l'aube and Guillaume et Nathalie. However, inasmuch as Bain de lune can be read as a hypercritical assessment of the impractical solutions that literary works propose for real-world problems, it is nonetheless true that the novel remains a work of literature itself and, as such, does not entirely turn its back on what - to return to Huggan - can be described as "the potential of the environmental imagination to envision alternative worlds, both within and beyond the realm of everyday human experience, which might reinvigorate the continuing global struggle for social and ecological justice." ${ }^{.11}$ Indeed, in the final paragraph attributed to 
the pluralized narrative agent in Bain de lune, Abner's actions are depicted in idealized, abstract terms:

Alors, nous avons suivi Abner, tellement à son aise dans les bayahondes qui brouillaient la route devant nous. La route de demain. Ces halliers où nous ne voyions s'ouvrir aucune issue. Contrairement à nous, Abner, d'une machette invisible, semblait arracher les brousailles et avançait. Nous avons réglé notre pas sur le sien. ${ }^{72}$

Although Abner is named as the person who, in concert with members of the rival family, can save Anse Bleue ecologically, what is surprising about this parting image is how his machete is described. While it is deemed vital in order to advance through the bayahondes and thereby surmount the community's precarious environmental, political, and economic fate - a path that the pluralized narrative agent portrays as none other than a literal dead end ("nous ne voyions s'ouvrir aucune issue")-Abner's machete is described as invisible. This quality renders it necessary to interpret his actions and aspirations on an allegorical - that is, abstract - level. After all, insofar as the indiscernible qualities of the henceforth figurative machete call into question its very practicality and purpose, the pluralized narrative voice's last words amount to a blind leap of faith. In suggesting that the imagined "route de demain" is worthy of being followed - "Nous avons réglé notre pas sur le sien" - the collective voice therefore underscores the potential of literature as a whole, and to everyone.

By reflecting not only the world around us but also what has already been written about it, works of literature such as Bain de lune constitute a relentless, optimistic engagement with the issues that preoccupy us. In so doing, they propose an ever-evolving means by which we might grapple with these issues - for better or for worse, surely, but not without hope. In this respect, the so-called abstractions of literature prove instrumental to readers' comprehension of real places and populations in and over time. It is moreover for this reason that the concluding emphasis on accountability and justice in Bain de lune can be appreciated for its universal message with respect to communities and their immediate environment. In fact, not only does Russell Banks suggest in his introduction to the English translation of the novel that it is "set in Haiti only because that happens to be the world Yanick Lahens knows best" (4), but the author herself made a similar claim shortly after having been awarded Le Prix Fémina: "Je suis très sensible au fait que le jury a compris que cette histoire, si elle se passe en Haïti, est universelle." ${ }^{\prime 3}$ 
While Bain de lune can therefore be interpreted as subscribing to a global "ecological citizenship" that, as developed by Deane Curtin, "requires commitments to human, as well as wider ecological justice," I propose that Lahens's novel remains first and foremost a text of and about Haiti and, in particular - as suggested by the peritextual blurb with which this paper begins - the Haitian landscape. ${ }^{74}$ In this regard, I agree with Sapp, who suggests that, in Bain de lune, "Lahens shifts away from Haiti's role in a larger world to examine the importance of history for individual Haitians. ${ }^{.75}$ On the one hand, the composite of first-person singular and pluralized narratives recounting the stories of the Mésidor and Lafleur/Dorival families from the time of the American Occupation through Aristide's rise to power are testament to both the unmistakably Haitian political and historical context in which the events unfold and the progressively deteriorating ecosystem of Haiti that is not only everpresent in the novel but integral to the characters' lives across generations. On the other hand, the hypertextual relationship with Gouverneurs de la rosée firmly grounds Bain de lune in Haiti on a literary level - as a shared story of and a response to the relationships between Haitians and their immediate natural environment. In revisiting a precise literary space and time, Bain de lune encourages readers not only to return to a canonical work published seventy years prior but also to reconsider how solutions to unremitting social and environmental issues might be adapted - not adopted - according to evolving realities in Haiti today.

\section{Notes}

Acknowledgments: I would like to thank the anonymous readers who reviewed an earlier version of this article for the Fournal of Haitian Studies. Their advice was most insightful, valuable, and appreciated.

1 Lahens, Bain de lune, 11. The narrative agent representing the community of Anse Bleue also underscores the role of the natural environment in terms of understanding the long and bitter relationship between the families: "C'est dire qu'entre les Mésidor, le vent, la terre, l'eau et nous couve une histoire ancienne" (Lahens, Bain de lune, 20).

2 Dieulermesson Petit Frère describes the novel as being "inscrit dans le registre du roman paysan modern" (Petit Frère, "Bain de lune de Yanick Lahens").

3 Corzani, "Preface," vii, ix.

4 Marin La Meslé, "L’Haïtienne Yanick Lahens décroche le prix Femina."

5 Generally speaking, intertextuality refers to any relationship between texts. As defined by Gérard Genette, hypertextuality constitutes a more precise type 
of relationship "unissant un texte $\mathrm{B}$ (. . . hypertexte) à un texte antérieur A (. . . hypotexte)" (Genette, Palimpsestes, 11).

6 Buell, The Future of Environmental Criticism, 30. In his seminal work on the field of ecocriticism, Buell addresses the relationship between the world of the text and the world of historical or lived experience, arguing that discourses of and on the environment should be a constitutive part of literary studies.

7 For a discussion of the concept of "ecological citizenship," see Curtin, Chinnagounder's Challenge.

8 Lahens, La Couleur de l'aube, 142, emphasis added.

9 Lahens, Guillaume et Nathalie, 69, emphasis added.

10 This is of course not the case with Lahens's 2010 Failles, for instance, which is full of explicit intertextual references.

11 The different sermons by le père Bonin, separated by the death of the (innocent) stranger (Lahens, Bain de lune, 133, 159), are reminiscent of those by le père Paneloux in La Peste, which are punctuated by the death of the Othon child. Lahens makes direct or indirect reference to numerous works by Camus in Failles, including his writings in the French wartime newspaper Combat and the philosophical essay L'homme révolté. See Walsh, "The Global Frame," 298-300.

12 Condé, Traversée de la mangrove, 14. In terms of both storyline and narration, Lahens's novel immediately calls to mind Traversée de la Mangrove. The discovery of a lifeless body on the beach in the opening lines of Bain de lune proves in many ways reminiscent of Condé's iconic novel, with the important exception that, in contrast to Condé's Francis Sancher, who is never a narrative agent and whose voice is limited to the first- and third-person focalizations of other inhabitants of Guadeloupe's Rivière-au-Sel community, Lahens's deceased female protagonist narrates in the first person. Furthermore, on a narratological level, Bain de lune closely parallels Faulkner's As I Lay Dying, which is of course a text that Condé has recognized as influential in the writing of Traversée de la mangrove (see Françoise Pfaff, Conversations with Maryse Condé, 109). In Faulkner's novel, Addie Bundren, who narrates one of the chapters, lies dying in her home.

13 A homodiegetic narrator can be defined as a narrator who is also a character in the story being narrated.

14 Commonly referred to as a flashback, analepsis signifies a chronological break in the narration to an earlier point in the story. Sapp, "The Talking Dead," 119. Examples of intergenerational leitmotifs include the mysterious death of Bonal Lafleur, who happens to be Cétoute's great-great-grandfather (Lahens, Bain de lune, 12), and the death of a stranger to Anse Bleue later identified as a kamoken who opposed the Duvalier dictatorship (Lahens, Bain de lune, 147).

15 Onomastic refers generally to the science or study of names and words.

16 Lahens, Bain de lune, 22.

17 Ibid., 23, emphasis added. 
18 Ibid.

19 Ibid.

20 Ibid., 24, emphasis added. This passage of the novel is reminiscent of Traversée de la mangrove, in terms of both Francis Sancher's discussion with Rosa Ramsaran regarding his attempt to "démêler l'écheveau de la vie" (Condé, Traversée de la mangrove, 170) and the eponymous mangrove itself, which, as Francis notes, is never crossed: "On s'empale sur les racines des palétuviers. On s'enterre et on étouffe dans la boue saumâtre" (Ibid., 192). Each novel, then, opens with the discovery of a deceased individual followed by questions regarding the person's identity and past, and the difficulty of determining the desired answers. revitalize the suffering village of Fonds-Rouge, Manuel, upon his return, initially contributes to his parents' meager income by cutting down trees and preparing them to be used as charcoal, which Délira then hauls to the city to sell (Roumain, Gouverneurs de la rosée, 88). Roumain, Gouverneurs de la rosée, 111.

As is later the case with Bonal, Manuel is attacked from behind and feels "une douleur aiguë" (ibid., 199).

Jimmy Mésidor, another of the "prodigal sons" in Bain de lune, arrives in Anse Bleue from the United States: "Quand la 4 x 4 atteignit le sommet de ce qui semblait être le dernier sommet du monde, Anse Bleue s'offrit au regard de Jimmy dans sa totalité. La mer était une plaque luisante à perte de vue, posée là pour renvoyer toute la puissance du soleil, comme si la terre condamnée était prise entre deux fatalités, brûler ou être engloutie" (ibid., 243). However, indicative of the limits of this hypertextual leitmotif with respect to Gouverneurs, it is significant that - as opposed to Manuel and even Léosthène - it is the driver, not Jimmy, who laments the environmental degeneration of the region: 
"Le chauffeur s'était lancé dans une longue déploration sur cette terre qui, sans pudeur, montrait ses tripes et ses cicatrices. Abandonnée par tous. Jimmy restait sourd et indifférent à cette ritournelle pleurnicharde et ennuyeuse du chauffeur, à qui il demanda au bout d'un moment de se taire" (ibid., 242).

35 Ibid., 175. When Léosthène refamiliarizes himself with the region surrounding Anse Bleue after his return, it is clear that François Duvalier has come to power (ibid., 183-185).

36 Ibid., 175-176.

37 Ibid., 177, 181.

38 Ibid., 135-136.

39 Ibid., 187.

40 Ibid., 184.

${ }^{41}$ Ibid., 188.

42 Ibid.

43 Ibid., 15.

44 Ibid., 17. For this reason, my assessment of the first-person pluralized narrative agent in Bain de lune contrasts sharply with that proposed by Robert Sapp, for whom the second narrative voice (nous) notably evokes "the collective spirit of solidarity celebrated in Roumain's Gouverneurs de la rosée" (Sapp, "The Talking Dead," 123). While Sapp remarks the "ambiguous sense of community" that is embodied by the pluralized narrative voice, and suggests that "the collective reach of the nous does not extend equally to all the inhabitants of the region" (in particular to US Marines, landowners, and bourgeois shop owners represented primarily by the Mésidor family), he ultimately concludes: "This second narrative voice reveals the multiplicity of perspectives and motivations within a community, a collective nous" $(124,128)$. In my reading, human and environmental relationships in Bain de lune prove to be far removed from the socialist/communist sentiment prevalent in Roumain's novel, according to which resources might be - and eventually are - shared equally among a town's inhabitants. Hence, on the one hand, as Sapp argues, it is impossible to ignore or entirely discount particular individuals or factions in one's community (128). Sapp cites Bain de lune accordingly: "Tout redoutables et cruels qu'ils fussent, les Mésidor étaient des nôtres" (128; Lahens, Bain de lune, 39). On the other hand, it is nonetheless true, as the very next line of the novel makes clear, that the firstperson pluralized narrative agent is speaking on behalf of a particular group of Anse Bleue's inhabitants: "Nous en étions mêmes fiers" (39). Moreover, whereas class differences are essentially nonexistent in Gouverneurs, they only increase over time in Bain de lune, further dividing the community: "Les Mésidor . . . avaient depuis toujours convoité la terre, les femmes et les biens" (ibid., 21).

45 Ibid., 269, 15.

46 Ibid., 249. 
47 Ibid., 14-15, emphasis added. While Tertulien's desire to possess Olmène is described figuratively by way of a natural lexicon (that is, a lexicon that draws from nature), the love scene between Manuel and Annaïse in Gouverneurs de la rosée is, conversely, foreshadowed by way of a literal discourse that, in referring to the flora of the spring, serves to underline the fundamentally innocent nature of their relationship. Approaching the hidden spring, Annaïse observes, "Ça sent le frais, dit-elle, ça sent le vent et l'humide," after which, still referring to the hidden spring, she says "Montre-moi l'eau, Manuel" (Roumain, Gouverneurs de la rosée, 149, 150). When they first see each other, Tertulien is described as wearing a "chapeau de belle paille à large bord" (Lahens, Bain de lune, 13) and is guessed to be around fifty-five years old, Olmène being barely sixteen (Ibid., 15). While Annaïse and Manuel are much closer to each other in age, when they first meet in Roumain's novel, Manuel is notably wearing a hat very similar to the one worn by Tertulien, with the evident exception of its aesthetic qualities given the difference in status between the two men: "Il toucha le large bord de son chapeau de paille et le camion démarra" (Roumain, Gouverneurs de la rosée, 35, emphasis added).

Lahens, Bain de lune, 98. near-perfect ending is arguably utopic in nature. For a recent study of the realism in/of Roumain's novel, see Leak, "The Nonmagical Realism of Jacques Roumain's Gouverneurs de la rosée."

63 Roumain, Gouverneurs de la rosée, 204. "Bientôt cette plaine aride se couvrirait d'une haute verdure; dans les jardins pousseraient les bananiers, le maïs, les patates" (ibid., 244).

64 Lahens, Bain de lune, 31. 
65 Ibid., 261, emphasis added.

66 Sapp, "The Talking Dead," 123.

67 Lahens, Bain de lune, 239. It seems that Abner has not yet traveled abroad, which, in addition to his steadfast commitment to his immediate natural environment, further distinguishes him from all three prodigal sons.

68 Ibid.

69 Ibid., emphasis added.

70 Ibid., 240, emphasis added.

71 Huggan, "Greening' Postcolonialism," 721.

72 Lahens, Bain de lune, 262. It is interesting to note in passing the hypertextual significance of this passage in terms of the decidedly uncrossable and deadly mangrove in Condé's Traversée de la mangrove: "On s'empale sur les racines des paletuviers. On s'enterre et on étouffe dans la boue saumâtre" (Condé, Traversée de la mangrove, 192).

73 Banks, "Introduction," 4; Chaplain Riou, "Le Femina prend le large."

74 I quote Huggan's summary of Curtin; see Huggan, “'Greening' Postcolonialism: Ecocritical Perspectives," 703. See also Curtin, Chinnagounder's Challenge.

75 Sapp, "The Talking Dead," 121.

\section{Bibliography}

Banks, Russell. "Introduction.” In Moonbath, by Yanick Lahens, 3-5. Dallas: Deep Vellum Publishing, 2017.

Buell, Lawrence. The Future of Environmental Criticism: Environmental Crisis and Literary Imagination. Malden, MA: Blackwell Publishing, 2005.

Camus, Albert. La Peste. 1947; repr. Paris: Gallimard, 1972.

Chaplain Riou, Myriam. "Le Femina prend le large en sacrant l'Haïtienne Yanick Lahens." Le Point, November 3, 2014. http://www.lepoint.fr/culture/le-feminaprend-le-large-en-sacrant-l-haitienne-yanick-lahens-03-11-2014-1878301_3. php\#xtmc $=$ bain-de-lune \&xtnp $=1 \& x t c r=3$.

Condé, Maryse. Traversée de la mangrove. Paris: Mercure de France, 1989.

Corzani, Jack. "Preface." In Gouverneurs de la rosée, by Jacques Roumain, vii-xvi. Fort-de-France, Martinique: Éditions Émile Désormeaux, 1977.Curtin, Deane. Chinnagounder's Challenge: The Question of Ecological Citizenship. Bloomington: Indiana University Press, 1999.

Dubois, Laurent. "Who Will Speak for Haiti's Trees?" New York Times, October 17, 2016. https://www.nytimes.com/2016/10/18/opinion/who-will-speakfor-haitis-trees.html. 
Genette, Gérard. Palimpsestes. La littérature au second degré. Paris: Seuil, 1982.

Huggan, Graham. “'Greening’ Postcolonialism: Ecocritical Perspectives.” Modern Fiction Studies 50, no. 3 (2004): 701-733.

Lahens, Yanick. Bain de lune. Paris: Sabine Wespieser, 2014.

—. La Couleur de l'aube. Paris: Sabine Wespieser, 2008.

_. Failles. Paris: Sabine Wespieser, 2010.

- Guillaume et Nathalie. Paris: Sabine Wespieser, 2013.

Lahens, Yanick, with Alfred Cage Alexandre, Nicole Pineau, Gisèle Rosier, and Jean-Marc Lahens. "Table ronde : Littératures caribéennes au présent : Histoire(s) en Relation, nouveaux partages éc(h)o-poétiques." 3 le Congrès Mondial du Conseil International d'Études Francophones, Université des Antilles, June 26-27, 2017. http://www.manioc.org/fichiers/V17155.

Leak, Andrew. "The Nonmagical Realism of Jacques Roumain's Gouverneurs de la rosée." Fournal of Haitian Studies 23, no. 1 (2017): 135-159.

Marin La Meslé, Valérie. "L'Haïtienne Yanick Lahens décroche le prix Femina." Le Point, November 3, 2014. http://www.lepoint.fr/livres/l-haitienne-yanicklahens-decroche-le-prix-femina-03-11-2014-1878246_37.php\#xtmc=bain-delune\&xtnp $=1 \& x \operatorname{xt}=2$.

Munro, Martin. Writing on the Fault Line: Haitian Literature and the Earthquake of 2010. Liverpool: Liverpool University Press, 2014.

Petit Frère, Dieulermesson. "Bain de lune de Yanick Lahens traduit en anglais." Le Nouvelliste, September 27, 2016. http://lenouvelliste.com/lenouvelliste/ article/163626/Bain-de-lune-de-Yanick-Lahens-traduit-en-anglais.

Pfaff, Françoise. Conversations with Marye Condé. Lincoln: University of Nebraska Press, 1996.

Roumain, Jacques. Gouverneurs de la rosée. 1944; repr. Fort-de-France, Martinique: Éditions Émile Désormeaux, 1977.

Sapp, Robert. "The Talking Dead: Narrating the Past in Yanick Lahens's Bain de lune." Journal of Haitian Studies 23, no. 1 (2017): 119-134.

da Silveira, Luiz Augusto. "The Dialectics of Jacques Roumain's Masters of the Dew." Ensaios e Paios, November 26, 2012. http:/ / ensaiosepaios.blogspot.com/.

Walsh, John Patrick. "The Global Frame of Haiti in Yanick Lahens' Failles." Contemporary French and Francophone Studies 19, no. 3 (2015): 293-302. 